Article

\title{
Applications of Stratigraphic Analysis to Enhance the Inspection and Structural Characterization of Historic Bridges
}

\author{
Francesca Savini $^{1}\left(\mathbb{D}\right.$, Carlo Rainieri ${ }^{2, *(\mathbb{D})}$, Giovanni Fabbrocino ${ }^{1,3}$ and Ilaria Trizio $^{1}$ (D) \\ 1 Institute for Construction Technologies, National Research Council of Italy, Secondary Branch of L'Aquila, \\ 67100 L'Aquila, Italy; savini@itc.cnr.it (F.S.); fabbrocino@itc.cnr.it (G.F.); ilaria.trizio@itc.cnr.it (I.T.) \\ 2 Institute for Construction Technologies, National Research Council of Italy, Secondary Branch of Naples, \\ 80146 Naples, Italy \\ 3 Department of Biosciences and Territory, University of Molise, 86100 Campobasso, Italy \\ * Correspondence: rainieri@itc.cnr.it
}

Citation: Savini, F.; Rainieri, C.;

Fabbrocino, G.; Trizio, I. Applications of Stratigraphic Analysis to Enhance the Inspection and Structural Characterization of Historic Bridges. Infrastructures 2021, 6, 7. https://doi. org/10.3390/infrastructures6010007

Received: 1 December 2020 Accepted: 31 December 2020 Published: 7 January 2021

Publisher's Note: MDPI stays neutral with regard to jurisdictional clai$\mathrm{ms}$ in published maps and institutional affiliations.

Copyright: $(2021$ by the authors. Licensee MDPI, Basel, Switzerland. This article is an open access article distributed under the terms and conditions of the Creative Commons Attribution (CC BY) license (https:// creativecommons.org/licenses/by/ $4.0 /)$.

\begin{abstract}
Road networks are disseminated of bridge structures whose typology reflects the time of design and construction of the transportation infrastructure and its relevance in the reference geographical area. Among others, masonry bridges are still widely operational, especially in those regions affected by a limited urbanization and a very high landscape value. As a consequence, the maintenance and the reliability of existing structures is a key issue for owners and managers of road and railway infrastructures. This circumstance leads to the development of an integrated approach able to cover the needs of knowledge of the technological and structural features of the bridge along with its history and current conditions. The main contribution of the study lies in the implementation of such an interdisciplinary approach through the application of archaeological stratigraphic method and 3D data management to historical masonry bridges. The survey and inspection protocol, whose first results are here presented, aims to improve the knowledge of the assets, and facilitate the visual inspection. The results refer to a road infrastructure located along the Aterno River in the surroundings of L'Aquila (Central Italy) and point out promising perspectives in terms of feasibility and scalability of the approach to large stocks of assets.
\end{abstract}

Keywords: masonry bridges; infrastructure conservation; archaeological analysis of bridges; knowledge of historical artifact; historical bridges; inspection and maintenance

\section{Introduction}

Design and erection of buildings and infrastructures reflect the scientific and technical knowledge of the time of construction, but they point out also the expected performance associated to given loading scenarios. As a consequence, it is worth noting that the assessment and management of existing structures and infrastructures is a task far more complicated compared to the design and construction of new ones, which have been deserved to those regions with high levels of urbanization and industrialization [1,2].

The latest catastrophic events affecting road infrastructures in Europe, and particularly in Italy, have brought up again the issue of bridge maintenance and safety to the center of technical and scientific debate. As part of this, new guidelines for the management and safety of existing bridges have recently been developed and released by the Italian Ministry of Infrastructures and Transportation, mainly to evaluate and classify risks of those structures made of reinforced concrete, structural steel, or composite members [3], more in general, all the structural types that have been built after the Second World War in many European and Mediterranean countries [4,5].

It is clear that the spotlight is at the moment focused on those bridges that serve critical infrastructures. However, there are many masonry structures located in the historical centers of European cities and villages as well as many operational bridges outside developed and urbanized areas (the so-called Inner Areas [6,7]) that need to be accurately inspected 
and maintained. Due to the time of design and erection, masonry bridges can be addressed as historical structures, so that approaches and techniques developed for this specific class of structures [8] should be taken in proper consideration. As a result, maintenance of these structures means preserving safety and reliability of the infrastructure, but also conservation of historical assets and preservation of the landscape. This circumstance changes the technical perspective of the problem and leads to recognize the need of extending and optimizing common approaches for architectural heritage to distributed networks of valuable structures.

Although an extensive review of the state of the art on the subject is not the aim of this paper, several investigations and studies can be found in the technical literature; in most cases these studies are aimed at monitoring the state of the infrastructures in order to assess their safety. The classical studies in the structural field aimed at evaluating the mechanical behavior of the artifacts, the characterization and state of conservation of the component materials, their seismic vulnerability and structural modeling for the safety of road and railway bridges [9-18].

Those studies are being supported by others aimed at integrating different tools and methods for an in-depth level of knowledge of these artifacts. In this sense, the attempts aimed at integrating digital photogrammetry procedures with non-destructive testing techniques, structural analyses, and virtual reality open the way to really attractive applications [19-21]. Another class of examples relies on Building Information Modeling (BIM) and deals with the development of parametric models to enable a digital management of the data resulting from the inspections and maintenance of the assets [22-25].

Another viewpoint on the same topic is offered by those studies aimed at stimulating and enhancing knowledge of intangible characteristics, historical reconstruction, and the dissemination, in virtual environments, of masonry bridges through metrological approach and typological, architectural, and geometric-form investigations of the artifacts [26-29].

Road infrastructures are also objects of the study of archaeology as they allow for the reconstruction of the road system and its evolution related to the history of the settlements. This is a founding argument of Road Archaeology, which combines different methods, from geomorphology to the reconstruction of road layouts and their extent also based on the type of transit they were subjected to in the past [30-32]. The bridges are a direct source and can be analyzed by the stratigraphic method of masonries for knowledge [33-35], but also for restoration projects [36]. A lack of integration between the technical and humanistic investigation is conversely found both in the case of the single bridge and the stock belonging to a network. The archaeology approach is worth investigation since a detailed analysis of the single structure can be implemented according to the available literature and practices related to historical constructions.

Therefore, the present paper represents a contribution to the development of knowledge in the area of the inspection and maintenance of masonry bridges by using a multidisciplinary perspective and connecting the results of the analyses carried out by the hard sciences with archaeological studies. In particular, the attention is first focused on the assessment of the role of the so-called stratigraphic method-a privileged tool for the archaeological investigation of excavation and historical buildings-in the structural and condition assessment of masonry bridges. This method is used in accordance with other types of knowledge, such as damage identification and surface conservation assessment, but also the chemical, physical analysis, and technological characteristics of the construction materials or the evaluation of empirical knowledge of the ways of building.

The research is aimed at designing and assessing a workflow able to satisfy the needs of tracing the current conditions of historical masonry bridges and collect quantitative and qualitative data propaedeutic to the functional and performance assessment of the asset, taking into proper consideration preservation of historical and landscape values.

The attention is particularly focused on the assessment of the effectiveness of the approach to serve as a rational procedure able to support the technical personnel involved 
in structural diagnostics and inspection of the historical masonry structures belonging to road infrastructures.

As a consequence, the presentation of the different phases of the workflow is carried out along with the presentation of the results achieved on real structures belonging to a road network located in the Aterno River area, in the surroundings of L'Aquila, Abruzzo region. This is not a limitation of the work since its scalability and repeatability in other geographical areas and its adaptability to chronologically and typologically different historical masonry infrastructures is ensured.

The work is thus aimed at demonstrating the effectiveness of stratigraphic analysis to improve the inspection and structural characterization of historical bridges. In fact, the application of the stratigraphic method has made it possible to argue the reconstruction of the bridge construction history, its evolution over time, identification, and assessment of any interventions carried out on the structure combining performance assurance and preservation of any intangible aspect.

The article is organized as follows. Section 2 introduces the archaeology analysis of the existing masonry bridges, moving from the description of the stratigraphic method applied to masonry, according to the approach of archaeology of building, the extension of the method to bridges is exemplified referring to the real case study of the Aterno River road network. Section 3 is devoted to discussing the application of the proposed method for the inspection and monitoring of bridges and report some results of the analyses in the selected reference area. Finally, Section 4 collects a brief discussion of the results and final remarks.

\section{Archaeology Analysis of Masonry Bridges for the Infrastructure Inspection}

The statement of the problem and the early validation of the approach are made with reference to real structures, some of them still under service (Figure 1), located in the area of the Aterno River Valley, which is located in the Abruzzo region, Central Italy. The Aterno River with its canals and tributaries represents one of the main hydrographic basins of the Abruzzo region and an area highly developed in the past due to the presence of many industrial settlements such as water mills and paper mills around L'Aquila, which is the main city of the area [37]. This represents an attractive test field as the road layout dates back to the first historical settlements in the area with still operational bridges.

The research started with the census of all the infrastructures crossing the river and their subsequent typological classification and based on their use (they were divided into road and railway bridges). The survey, structured in a multiscale and multilevel perspective starting from the basic knowledge of the area in question (morphology of the territory, administrative-functional organization, historical and current viability), developed from the implementation of a specific georeferenced database, which has been progressively expanded with the addition of specific themes.

The first census of the Aterno River area highlighted a massive presence of historic masonry bridges in the area and, above all, their continued use over time, simultaneously underlining the importance and legibility of the ancient road system. To these considerations were added those related to the problems with some of these historic bridges, such as their state of conservation, in particular for those currently neglected, the modified load conditions on those still in use, and the hydrogeological risk to which many of them are periodically submitted. 


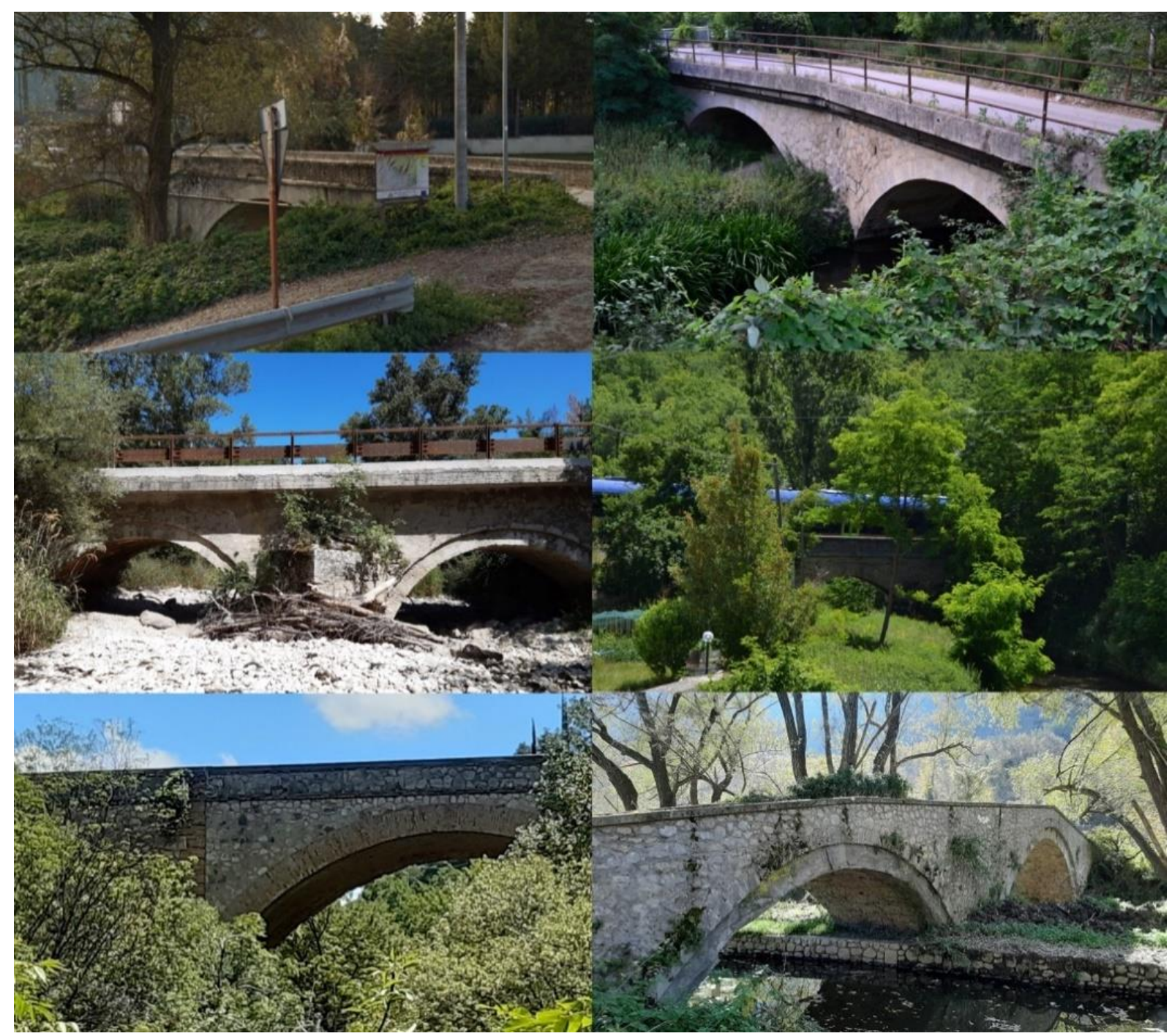

Figure 1. Arch masonry bridges under service on the Aterno River.

In the light of the previous considerations, the research is aimed at defining a procedure that, starting with the integration of the results of a multidisciplinary study for increasing knowledge, is able to provide a digital tool for the inspection and maintenance of historical masonry bridges. The knowledge will be obtained with geometric-formal, historical, and typological analyses, but also with those relating to the state of conservation and archaeological analyses of the masonries. The results are the basis for the creation of a digital information system and of a subsequent parametric model that allows the managing and sharing of the data, thereby supporting the planning of any interventions and subsequent monitoring and maintenance phases.

Therefore, the historical masonry bridges over the Aterno River were analyzed by integrating different techniques from diagnostic analyses to the most recent ones of threedimensional digital representation of cultural heritage artifacts. The strength of the research that the team is carrying out is developed by the interaction with procedures normally used in the field of archaeology, that is, analyzing the bridges structures with the methodologies of archaeology of buildings.

Describing the archaeology of building in a few pages is difficult, especially because the discipline varies considerably from one country to another based on traditions [38]. In this paper a brief summary is reported in relation to the Italian context.

This field of investigation has developed since the 1970s of the last century within the branch of Medieval Archaeology, applying the method typical of excavation to his- 
toric buildings through the stratigraphic analysis of masonries [39-42]. Archaeology of building uses the artifact itself as its main historical source and enhances the other types of knowledge with the results of stratigraphic analysis of masonries.

This analysis is aimed at identifying each of several sections that are part of construction, called Stratigraphic Unity of Masonries (SUM). The SUMs are distinguished based on: (i) the homogeneity of the masonry; the characteristics of the materials that compose it and their installation; (ii) the presence of elements inside the masonry; (iii) the traces left by the tools used for the construction of the artifact [43]. Each SUM identified on the surface of the masonry refers itself to the traces of the individual actions (constructions, collapses, restorations) carried out over time and can be traced back to a specific activity, constructive or destructive, that has been undertaken.

For each unit, the physical contacts existing between neighboring stratigraphic units are analyzed. In this way, it is possible to identify the relative chronological relationships of the various constructive actions: each unit can be contemporary, prior or subsequent to the neighboring one. The collected data are recorded on a special form sheet and the stratigraphic relationships indicated in a diagram called a matrix or Harris' diagram, as well as on the graphic representation provided by the survey. These supports are increasingly integrated with digital techniques both for data recording [44-47] and for the plane-volumetric acquisition. Graphic representation is increasingly digital thanks to the development of laser scanning and photogrammetric techniques [48-54] that are able to exploit the potential of the three-dimensional data already understood after the 1980s [55].

The implementation of the stratigraphic method constitutes the first phase of an overall study of the structure that is not exclusive to the archaeological discipline but rather applies to multiple research themes, such as restoration or the history of architecture [56-58] and introduces the analyses relating to construction techniques that respond to functional requirements and the laws of statics [59]. This method is used by different professionals and it directs towards a multidisciplinary approach for study of historical artifacts.

In Italy but also in Spain and France, the first interdisciplinary tables for discussion began, and already at the end of the 1990s of the last century yielded specialized journals such as "Archeologia dell'Architettura", "Arqueologia de la Arquitettura", and "Bulletin du center d'étues médiéval d'Auxerre". Today this branch of knowledge has acquired greater maturity thanks to the development of multiple researches and the application of advanced digital technologies and is beginning to assume, more in the academic field than in reality, an important role in urban and territorial planning.

In this way, it is possible to analyze the different stages of construction: the construction of the works, studying the choices made and their interaction with the environment; the life phase of the building which involves an inevitable evolution following possible collapses and superfetation due to historical maintenance and restoration interventions (to be correlated to historical anthropic or natural events such as hydrogeological instability) and, in some cases, the phase of abandonment.

The potential of this method is not limited to the identification of the stratification and the subsequent identification of a sequence of constructive and destructive phases since the discipline is increasingly oriented towards greater complexity [60,61]. In fact, the study of individual infrastructural and architectural works, enriched by comparative analyses and with those on published and unpublished sources, allows us to reconstruct the settlement dynamics of a territory, the viability related to the diffusion of trade and technological knowledge, construction techniques and the empirical skills of the workers, the settlement structure, and the continuity of use of the works, defining not only the material aspects but also the social and economic ones connected to the artifacts being analyzed.

The operating procedure for the bridge analysis started from the territorial and spatial analysis by means of the survey and the GIS recording of the masonry infrastructures (and not) located in the Aterno Valley. For the systematic collection data, the creation of a general database was prepared; this was carried out on the basis of the ministerial forms and can be increased by connecting relational DBs with the thematic results of the research. 
The interoperability and the possibility of constant updating with specific records, such as those derived from the forms for assessing the state of bridges already in use [62], are the strength of the system. An open photographic database for historical bridges has been also prepared, which can be updated and expanded over time thanks to crowdsensing techniques. This allows to keep track of the interventions that are carried out on the structures but also to understand the degradation through the comparison of the images over time [63].

The images produced with specific photographic campaigns are processed to obtain photogrammetric surveys that can be integrated with laser scanning techniques. Stratigraphic analyses of the masonries are carried out on some selected artifacts to understand the evolutionary history and to verify the presence or absence of collapses and renovations that can compromise the statics of the structure itself.

The knowledge of the historical evolution obtained by archaeologically interpreting the congruence or otherwise of the various parts of the infrastructural works becomes a prerequisite to specific studies for monitoring the state of the work as diagnostic analysis or visual inspection.

It was therefore necessary to define the methods of organization, conservation and exchange of the multiple data resulting from multidisciplinary analyses. The creation of photorealistic three-dimensional models, subsequently semantic with the archaeological results, is a fundamental step in the operational process. These models can be connected to the GIS database through external links and can be used online, but also offline on a 3D PDF: an easy-to-use tool that allows consultation of the three-dimensional data [64].

This tool performs different functions from the management and exchange of archaeological data to the support for visual inspection both remotely and in the field using mobile devices such as smartphones or tablets. Moreover, the $3 \mathrm{~d}$ PDF is a light and easy to manage interactive tool that enables the operator to access the data, even in conditions of no internet connection, and represents a good option for those authorities that are in charge of the management and maintenance of infrastructures located in the territory. The results of the archaeological research will be integrated with digital survey technologies in preparation of the implementation of an Historic Building Information Modeling (HBIM) [65] of masonry bridges.

\section{An Operational Framework for the Aterno Valley: Some Results}

The framework was structured in operational steps starting from an initial overall knowledge of the masonry infrastructural works up to a more in-depth study of a selected number of artifacts. The research needs led primarily to the identification of the area of interest, so that it could respond to very specific characteristics, such as the diversification of the types of infrastructure analyzed and the presence of multiple external risks to the artifacts. After examining the Abruzzo area on the basis of its geomorphological characteristics and the technical report of the Abruzzo region and professionals in the sector, the Aterno River basin was selected, which extends mainly in the territory of the province of L'Aquila (Figure 2).

This river originates within the boundaries of the municipality of Montereale and extends to about $96 \mathrm{~km}$, crossing the territory of 17 municipalities, until it enters the Pescara River, near Popoli, taking the name of this other river, and finally flows into the Adriatic Sea. The Aterno River basin is enriched not only by small natural and anthropic canalizations, but also by some tributaries such as the Raiale, the Raio and the Vetoio. This river and its area of interest were chosen because in addition to being exposed to a medium and high hydrogeological risk, with some areas particularly prone to flooding, it is characterized by the presence of different types of infrastructures that enrich the subject of the study.

In particular, in this area there are: ancient bridges no longer used and currently in a state of archaeological ruin, therefore subject to complex problems related to their conservation and use, including tourism; historical bridges still in use and currently integrated into the road system for which, since their construction, the load and traffic 
conditions have significantly changed; and masonry infrastructures relating to the railway line. The levels of knowledge envisaged by the research are structured in two phases, the first one relates to a basic knowledge and the second one to an in-depth level.
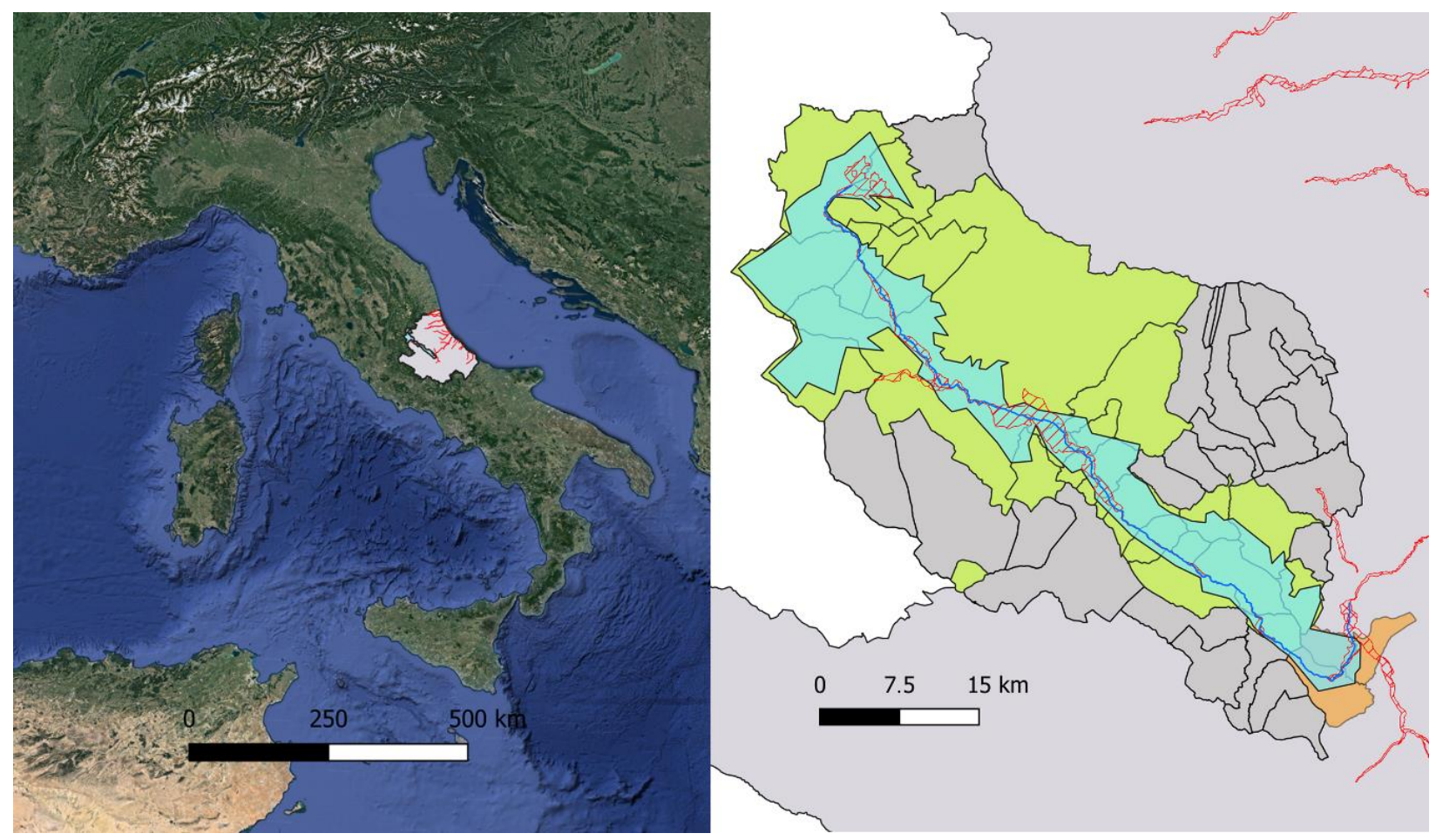

Figure 2. Satellite cartography of Italy with, on the right, an enlargement of the area relating to the Aterno River basin (with the areas subject to flooding highlighted with red outlines).

The first level of knowledge includes: census of the present infrastructures; research into the published sources for an understanding of the ancient road system and its transformation; a surface search for the identification of masonry structures; a photographic acquisition campaign and a compilation of special forms revised to fit ministerial guidelines; design of a relational database in a GIS environment for the management of multiple acquired data and its implementation; its export for online use with Google Maps tools.

The second level of knowledge involves: a selection of the artifacts based on their architectural characteristics, the type of structure, state of conservation and use (pedestrian, vehicular, railway); an integrated digital survey using laser and photogrammetric scanning techniques; a stratigraphic analysis of the elevated works; an analysis of the unpublished sources preserved in the State Archive of the city of L'Aquila to identify any maintenance, restoration or refurbishment interventions in the 19th and 20th centuries; a study of historical cartography and iconographic sources; an archaeological interpretation with the analysis of material and documentary sources, as well as with comparative surveys on the national territory.

\subsection{The Territorial Analysis and Spatial Distribution of the Bridges along the Aterno River}

The spatial analysis of the distribution of infrastructural works has been implemented in a GIS platform, whose potential in the management of territorial and geographic data is undisputed, as well as the ability to link topologically the data to georeferenced points. For this purpose, the QGIS Open-Source platform was used by setting the coordinate reference system WGS 84/UTM zone 33N and starting from the Google satellite map integrated with the regional cartography available on the Geoportal of the Abruzzo region [66].

The georeferencing of the infrastructures was carried out remotely using regional cartography, specifically the 1:25,000 IGM and the 1:5000 Regional Technical Map, integrated 
with orthophotos produced over the years. At present, more than 100 infrastructures relating to the pedestrian, road, motorway and railway system have been identified that cross the Aterno River. In parallel, a relational database (DB) was prepared with which to progressively implement the data of the multilevel surveys starting from general information (data on geometries, types, materials, etc.) to technical ones (state of conservation, transformation, dating, construction techniques and technologies etc.); into this DB a historical section was also prepared, in which to insert the findings from the State Archive (Figure 3).

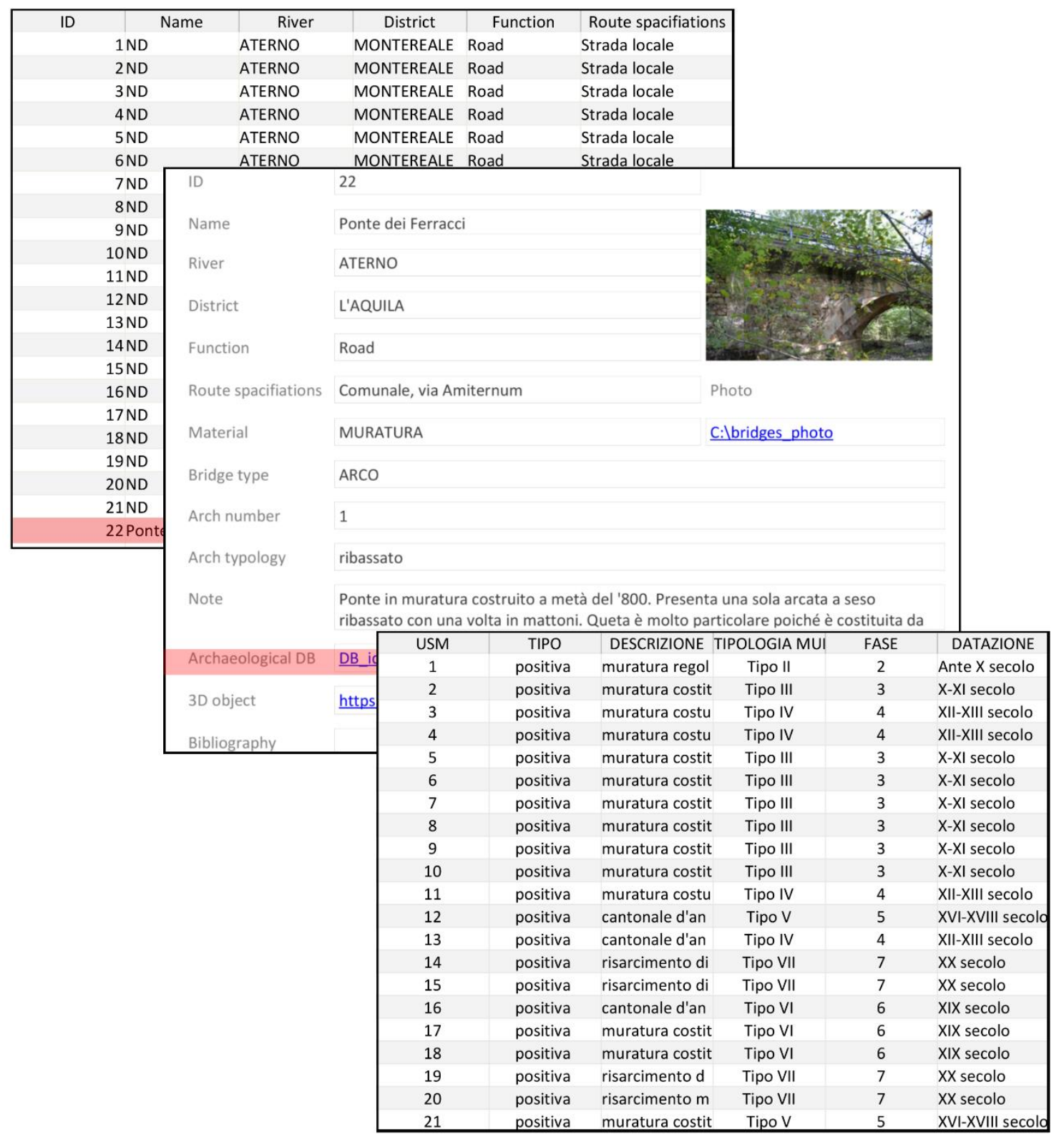

Figure 3. External relational database linked to the QGIS project.

The design of this Information System guarantees the management and use of alphanumeric and graphic information, the latter in particular made by photographic and three-dimensional format, with digital models that can be viewed thanks to external links activated with hyperlinks (Figure 4). 


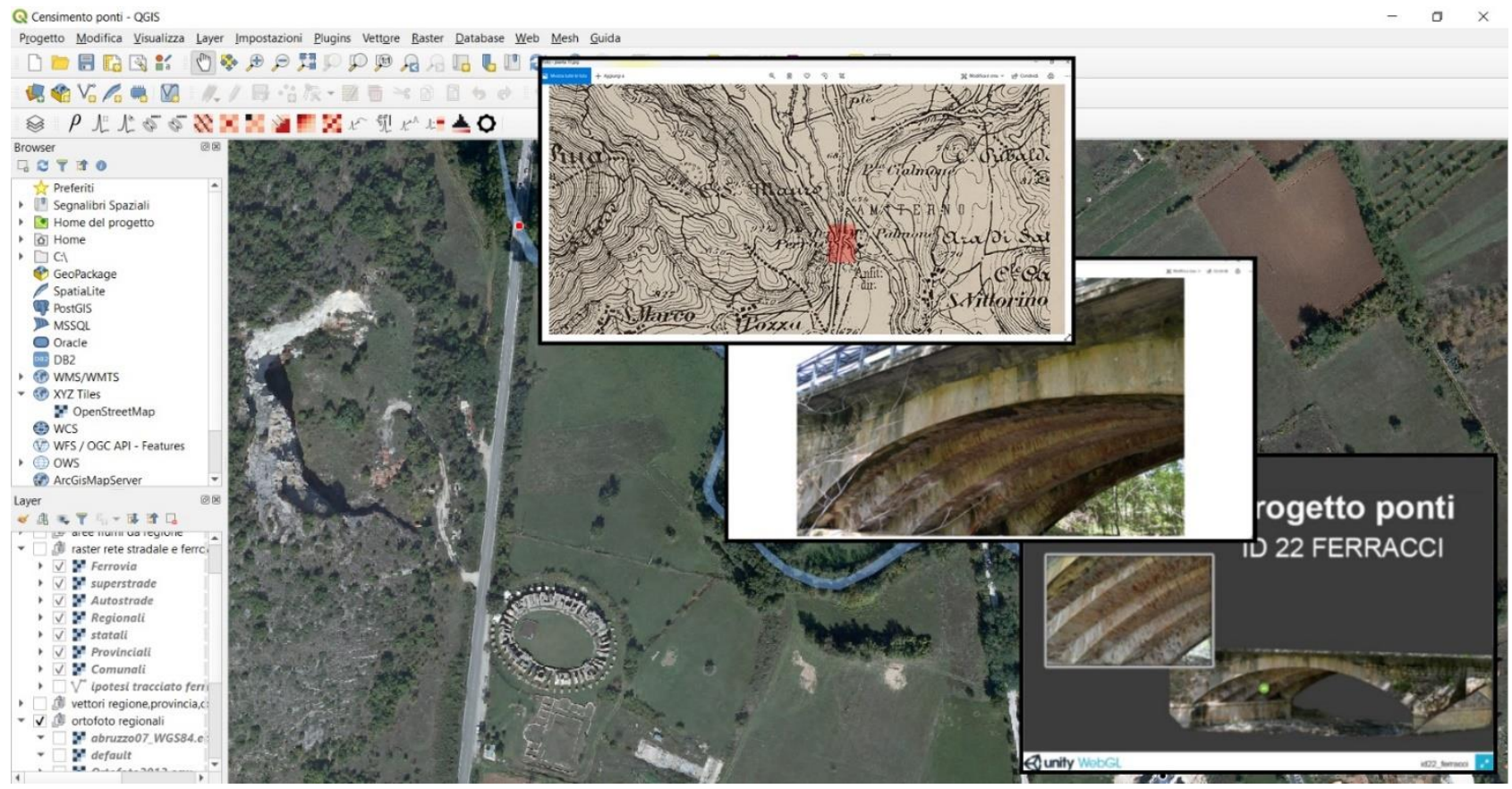

Figure 4. Screenshot of the QGIS project with external links (photo, historical cartography and three-dimensional model in WebGL).

The database linked to the georeferenced point elements has been exported in Keyhole Markup Language (KML) -an XML-based language created to manage geospatial data in three dimensions- this format allows viewing in "My Maps", a Google Maps application. This tool was used to reach the infrastructures in the territory recce phase, proving to be very useful during the on-site inspection and data recording operations (Figure 5). The surface survey was aimed at the photographic recording of all the infrastructures on the Aterno and the registration of their typology. For masonry bridges, the predefined fields of the form were then filled in directly on an ordinary smartphone.

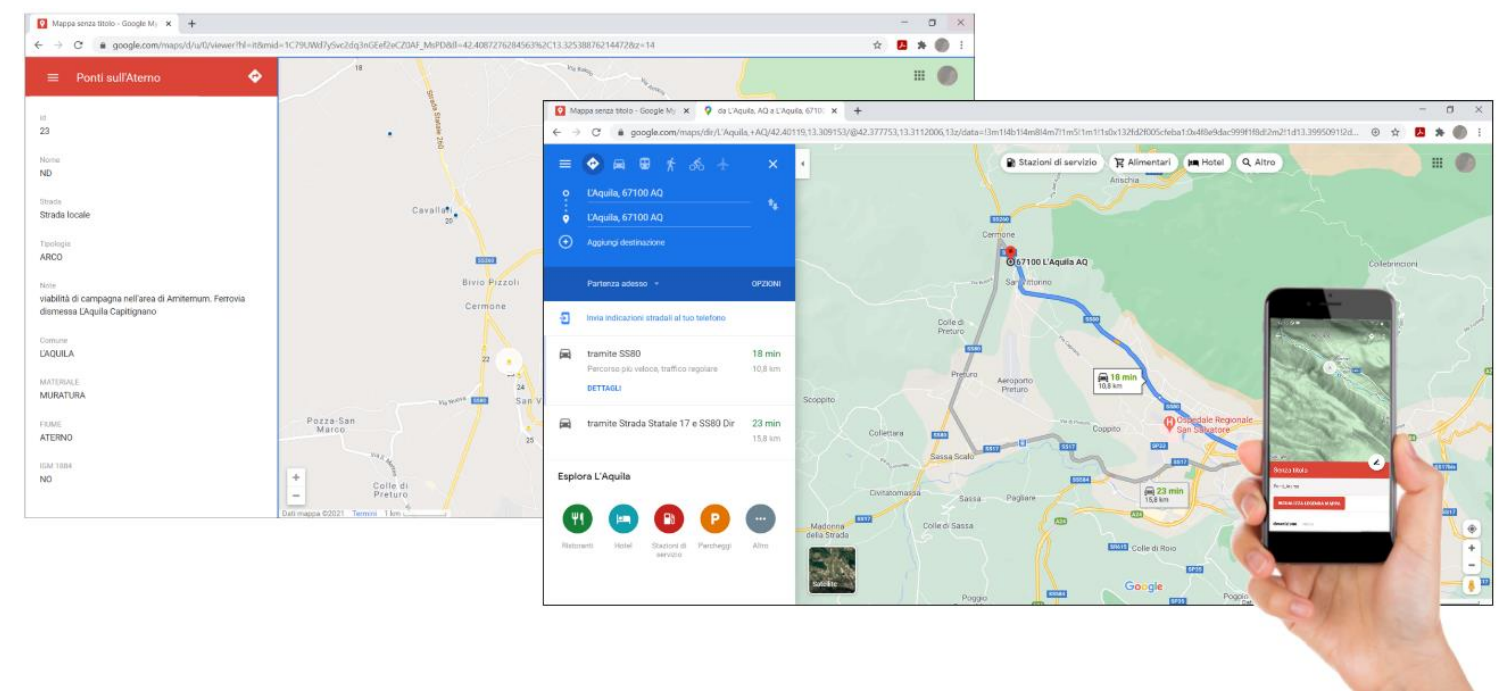

Figure 5. Census exported in KML format and usable on My Maps in desktop and mobile mode.

The masonry structures so far examined have been classified on the basis of functionality, type, and construction materials. There are abandoned and no longer used structures, bridges that can only be crossed on foot, and bridges that form part of the railway and road 
systems. The most representative typology is the masonry arch diversified in form (pointed arch, lowered arch or round arch) and in the number of assembled arches (Figure 6).

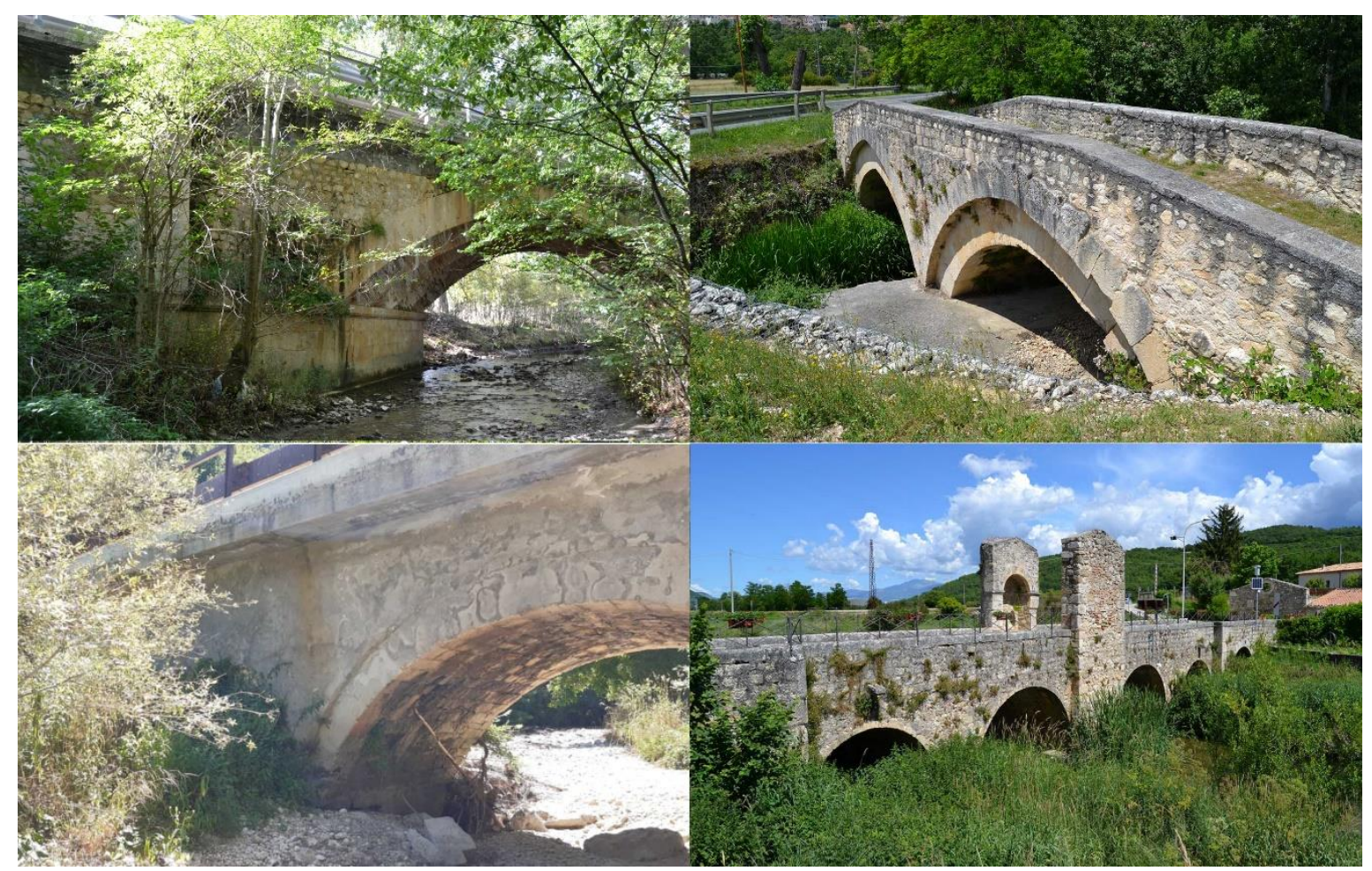

Figure 6. Photographic documentation of some arch masonry bridges along the Aterno River.

\subsection{Photographic and Photogrammetric Data Acquisition}

The results of the surveys highlighted the difficulty of detecting, even if only photographically, some structures due to excessive vegetation and, in some cases, for the inaccessibility of the land adjacent to the artifacts, privately owned or due to the high flow of the river. These aspects also affect the acquisition of the metric data with the integrated survey, which therefore must be appropriately designed also based on the season. In fact, the campaigns conducted in the summer months often had a negative outcome due to the thick vegetation found on the riverbanks. In autumn, photogrammetric surveying campaigns on two artifacts were made: the bridge in the locality of Cerro, in the municipality of Fossa, a few kilometers from L'Aquila, and the "Ferracci bridge" in the area of San Vittorino, a district of L'Aquila. The utmost difficulty encountered was with dense vegetation in some points and the inability to place the markers necessary to automate the digital photogrammetry procedure in the upper portions of the structure.

This problem was easily solved in the image processing phase with the manual addition of markers on the photos, carried out before generating the sparse cloud. This step ensured the success of the camera's alignment phase and the reduction of noise generated on the clouds by the reflection of the water surface in the photo's alignment phase. The generation of the models, carried out with the Agisoft's Metashape software (version 1.5.2), followed the workflow: editing of the images with masks; positioning of the targets manually on the photos; alignment of the cameras and the automatic positioning of the targets on the wall; generation of the dense point cloud; creation of the mesh and finally, creation of the overall textured and appropriately scaled model (Figure 7). The two acquisition campaigns were conducted with different devices. For the Ferracci bridges, dating back to the mid-19th century and characterized by a single lowered arch, it was acquired from the ground with a digital reflex camera (Nikon D3100). 


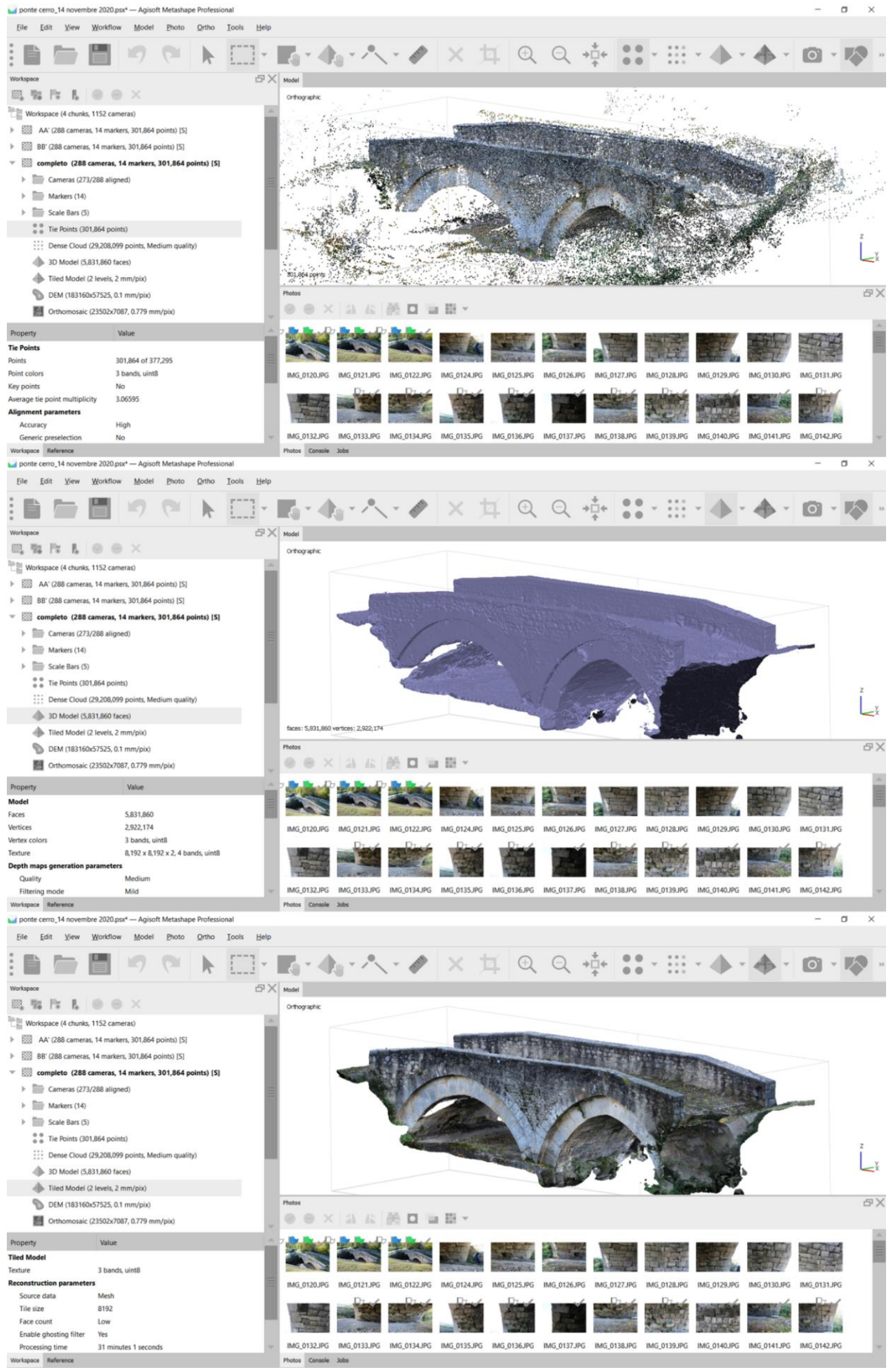

Figure 7. Phases of preparation of the photogrammetric model in Metashape software. 
The bridge in Cerro, dating back to the Middle Ages and no longer used today except as a pedestrian crossing, was detected with a digital reflex camera (Canon EOS4000D) mounted on a carbon fiber telescopic rod able to reach a maximum height of $8.50 \mathrm{~m}$. The two acquisition modes have produced different photogrammetric models, both validated in the metric and the color data, but with a different yield in the completeness of the mesh and in the quality of the related textures, demonstrating the effectiveness of the telescopic rod in the acquisition phase of the images.

The photogrammetric models were subsequently used as a support for an archaeological analysis on remote masonry and the orthomosaics generated by the software formed the basis of a critical survey obtained by mapping into them the results of the archaeological analysis.

\subsection{The Archaeological Stratigraphic Analysis of Historical Masonry Bridges}

Any analysis of historical masonry bridges must consider some aspects of the ancient road network that persist over time based on the continuity of mobility demand in the area and the continuous maintenance performed in time. The analysis of this complex system, crucial for people throughout the ages, relates to the historical events of a territory, as is the case of the Aterno River valley.

This area, surrounded by important mountain ranges, has been a natural link between the Sabina area and the Peligna Valley since ancient times, leading to the creation of a complex route that intersects the river. Our ancestors were faced with the problem of crossing the river, solved initially with fords or wooden structures that were subsequently replaced as part of the important territorial organization carried out in Roman times which involved the construction of 43 bridges over the Aterno River.

The surveyed area is characterized by important historical events, from prehistoric times to the Italic settlements, from the Roman conquest to the barbarian invasions, from the religious organization to the rise of fortified settlements, from the Suevian-Angevin to the Spanish dominions, up to modern times with the birth of the current municipalities.

Each historical period, characterized by precise political and economic choices, has played an important role in developing the road network by reconfigurations that have adapted the existing infrastructures to the needs of the new settlements [67], right up to the nineteenth century reorganization of the road network that provided the region with the road and rail network still in use [68].

For this reason, many masonry bridges attested in Roman times but restructured over time, are still part of the road system, as in the case of the Campana bridge, whereas other structures from different periods are in a complete state of disrepair and today in ruins, as is the case of the ancient bridge of Barisciano or the more recent one of Monticchio, both in the province of L'Aquila.

The monitoring of structures no longer in use must be considered as a central part of the cognitive process focused on the protection and conservation of these historical artifacts which, although they no longer accomplish their original function, must be preserved for their cultural value.

The signs of aging on these structures are evident if the artifacts are analyzed generally, that is according to the road system, and specifically in the single parts from which they are composed.

The bridge in the locality of Cerro (Figure 8), part of the municipality of Fossa, is at the side of the current municipal road that leads to the village and was the ancient crossing of the "Fossa stream", a channel of the Aterno River, which is still an important source of water for local agriculture. 

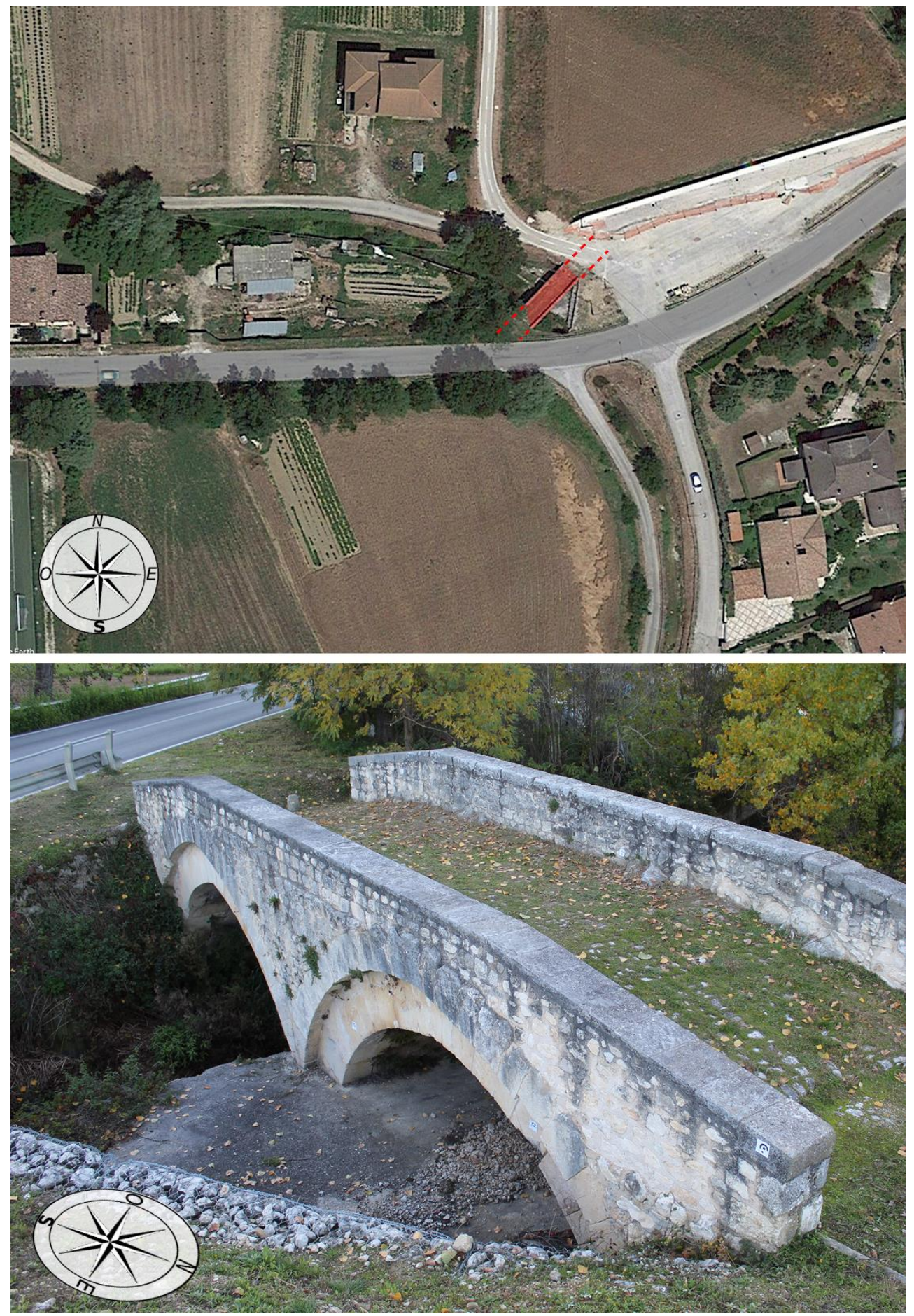

Figure 8. Bridge in the Cerro locality, in the territory of the municipality of Fossa, L'Aquila.

The structure of this bridge was oriented on a NE-SW axis and clearly part of an older road layout replaced by the current one which has an E-W setting. The bridge is characterized by two typologically different masonry arches, limestone parapets, and a paved surface. The canalization of the Aterno in this area has a lower range than the original one, since the riverbed was narrowed with the construction of a second embankment, partly in concrete, which partially obliterates the NE arch, in fact rendering it redundant.

In addition to this obvious transformation, the stratigraphic analysis of the bridge fronts (Figures 9 and 10) highlighted the presence of several SUMs, some referable to recent restoration work, others attributable to the first building phase visible on the masonry. 

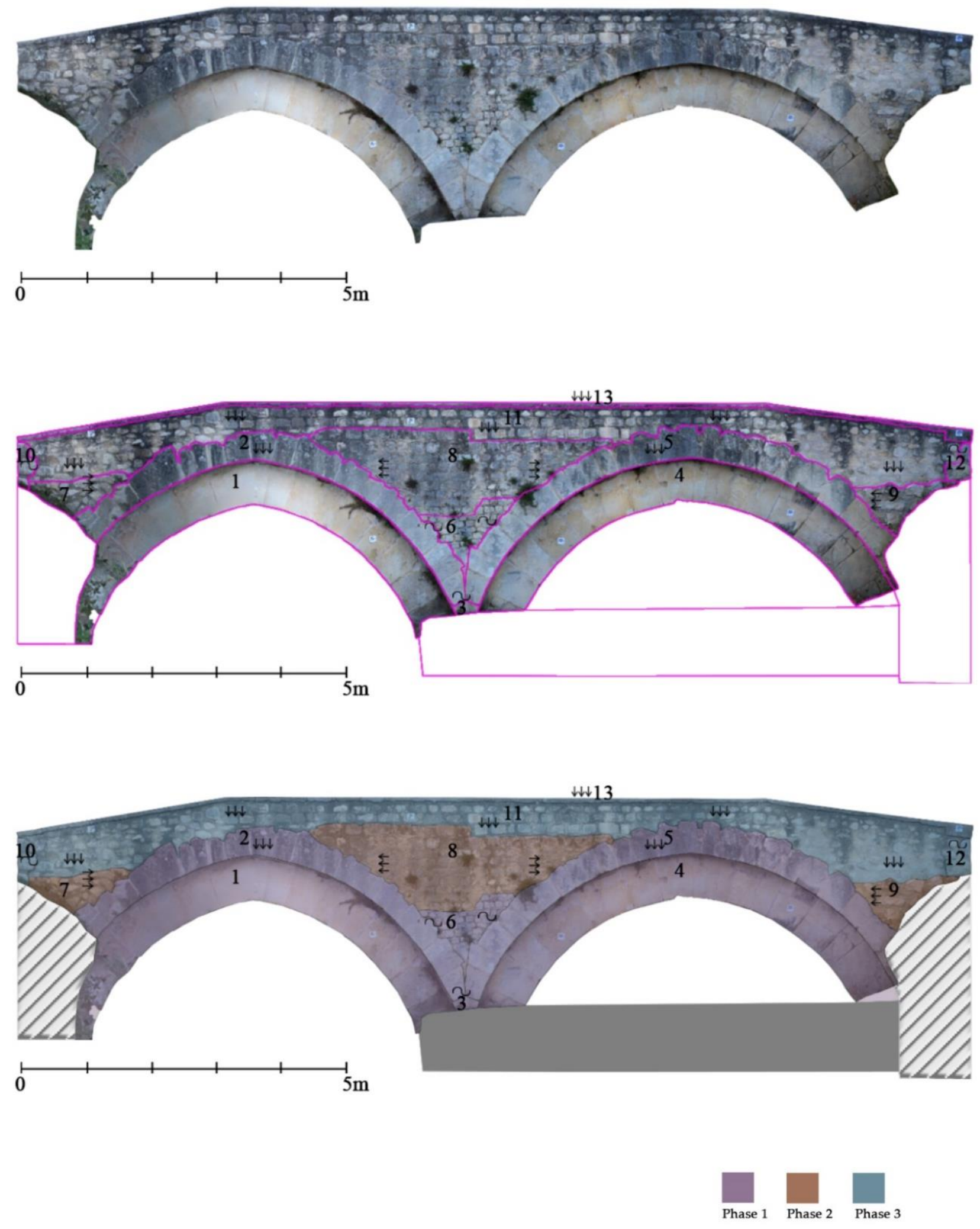

Figure 9. Stratigraphic analysis of the bridge's southeast front ( $\left.\mathrm{AA}^{\prime}\right)$ in the Cerro locality. 

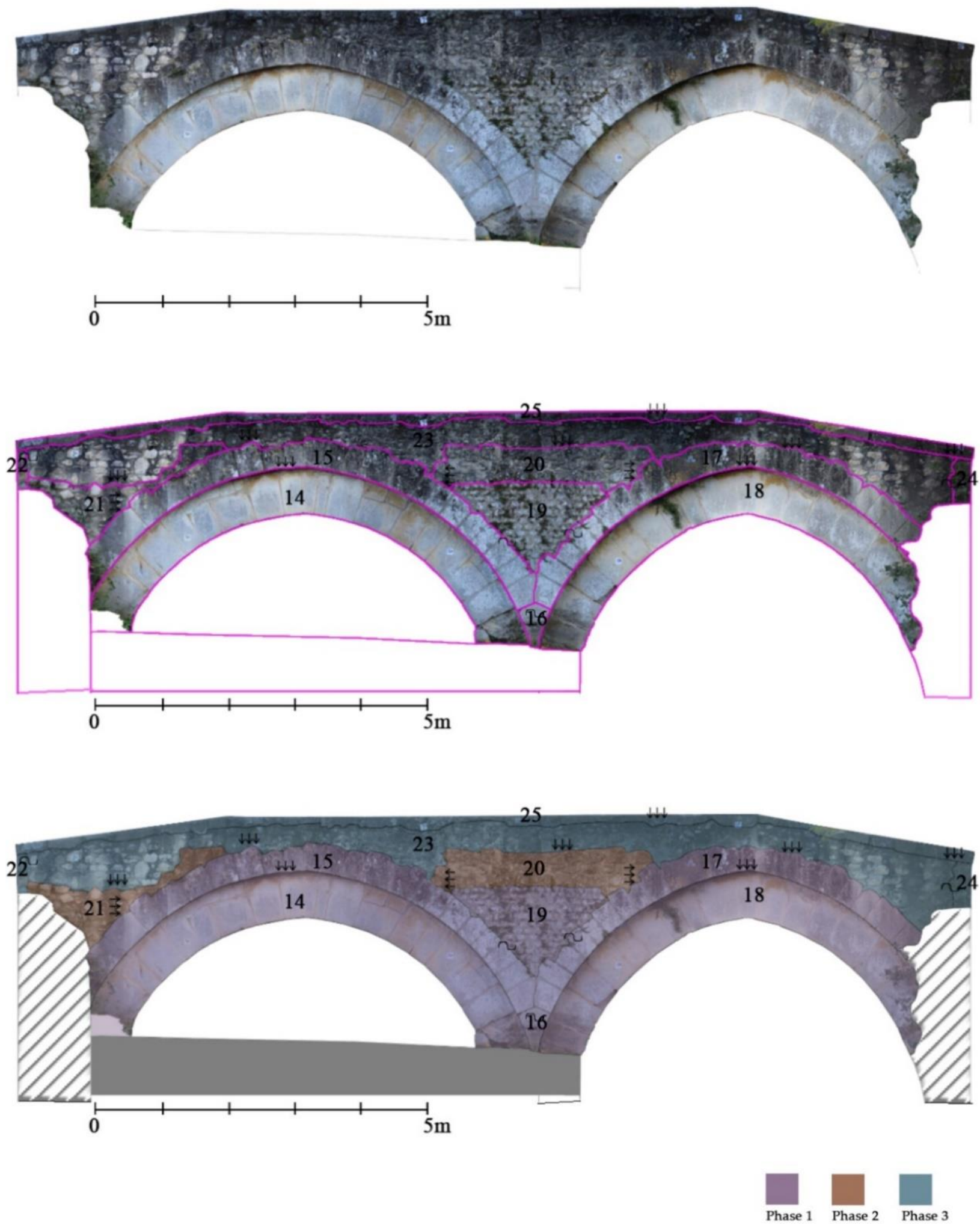

Figure 10. Stratigraphic analysis of the bridge's northwest front $\left(\mathrm{BB}^{\prime}\right)$ in the Cerro locality.

The two arches, one round and one pointed, are made with well-squared limestone pieces linked by fine light-colored mortar. On both faces of the bridge the two arches are surmounted by protruding ferrules, resting on the same ashlar that testifies the construction in the same phase. These upper arches are made with stones worked in the exposed face. In phase with this, the clearly detectable revetment can be placed between the two arches, 
mostly preserved on the NW-facing and made with masonry in small limestone ashlars placed in horizontal rows. The overlying masonry belongs to a subsequent phase, made of limestone ashlars placed in a repetitive pattern, in rows of small pieces alternating with rows made with larger elements. This masonry, clearly observable on both elevations, can be associated to extended repair/partial reconstruction works following a destructive event such as a collapse which, given the extension of the intervention, had likely damaged the structure (Figure 11).

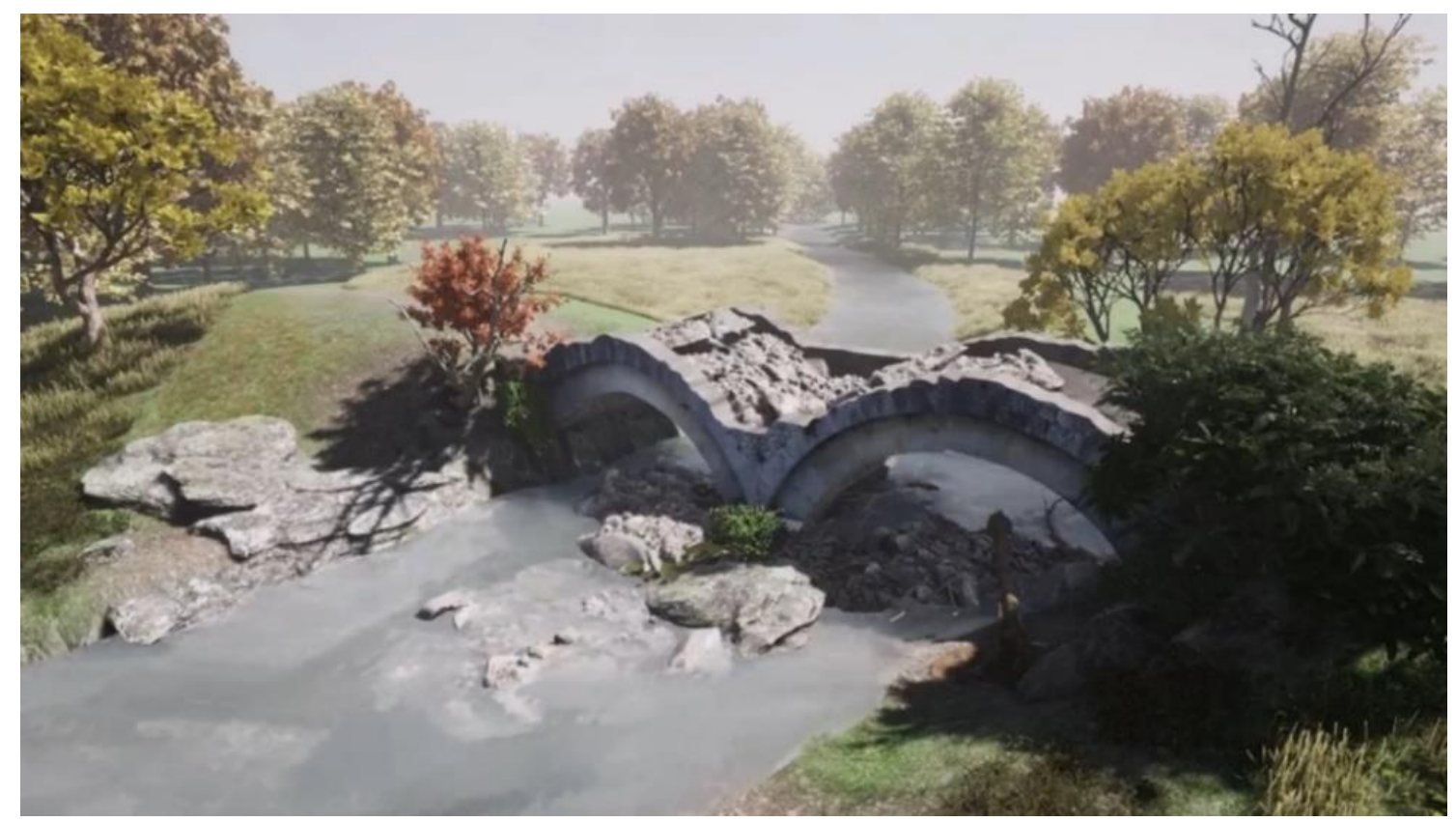

Figure 11. Virtual reconstruction of the bridge in the collapse phase (Reconstruction by A. Cordisco).

It is worth noting that the virtual reconstruction reported above represents a powerful tool for the design of diagnostic tests aimed at the detailed structural characterization of the bridge and can guide the iterative trial and error procedure that is recommended in the most advanced guidelines on the assessment of existing constructions [3,69-71].

The last restoration of the structure is evident on the two parapets of the bridge, done with medium and small-sized stones laid on sub-horizontal rows with abundant mortar on the SE elevation $\left(\mathrm{AA}^{\prime}\right)$ and with stones placed with greater irregularity on the NW one $\left(\mathrm{BB}^{\prime}\right)$. These masonries, although with different construction techniques and materials, can be identified as being part of the same phase by the will of who carried it out to signal the intervention with the back wall clearly visible, as well as in situ, on the Digital Surface Model (DSM) (Figure 12).

The DSMs are part of the Digital Elevation Model (DEM) technology that has been developed for terrain representation [72]. It represents the distribution of height from a reference plane of the points belonging to a given surface. This model, which was generated in the Agisoft's Metashape software (version 1.5.2) starting from the mesh of the artifact, represents the elevation values with a gradation of colors.

Archaeological documentation procedures based on DEM technology are mostly applied to excavation activities, but show potential if applied to masonries since they can highlight deformations of structures [73]. Elevation maps of fronts, if interpreted in a multidisciplinary perspective and integrated in HBIM, can provide information on the state of the structures and post-depositional deformations for the study of structural instabilities [74-76]. 

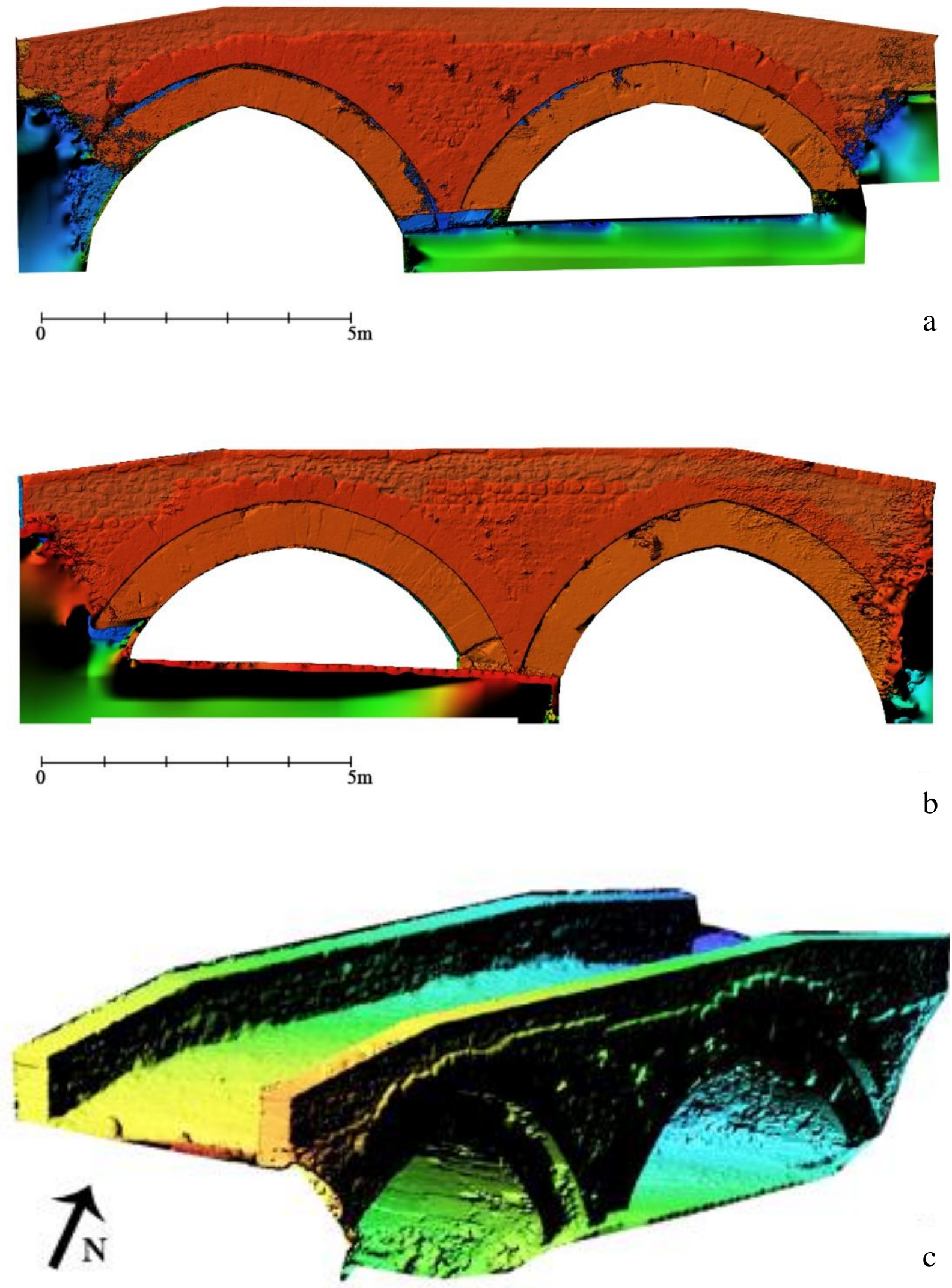

Figure 12. Digital Surface Model: (a) southeast front (AA'); (b) northwest front (BB'); (c) perspective view.

The SUMs analyzed are affected by traces of widespread surface degradation such as vegetation, crusts, and patinas. The few documentary sources relating to this artifact and the few data so far in possession regarding this portion of the territory do not permit 
us to link the stratigraphic analysis of the bridge to an absolute chronology, even if it is possible to imagine the bridge's structure dating back to the 13th century. The coexistence of two types of arches in the same structure has led many scholars to support the theory of a Roman pre-existence [66] relating to the road network that led to the nearby Roman city of Aveia. Research carried out so far does not confirm or negate these theories, but it is hoped that the in-depth study of the intrados of the arches, joined to a metric analysis of the stone elements, may bring new data in the absence of specific investigations, such as an archaeological excavation or analysis of mortars.

The results of the archaeological analysis conducted on the walls of the bridge and graphically summarized were integrated into a textured photogrammetric model by creating a semantic model (Figure 13), usable in 3D PDF format, but also online in WebGL mode starting from the QGIS project through a link, whose data can be implemented with those deriving from structural analyses to help monitor the conservation status of the building. This model can also be integrated with the mapping of degradation, which will facilitate a comparison over time with updated control acquisitions.
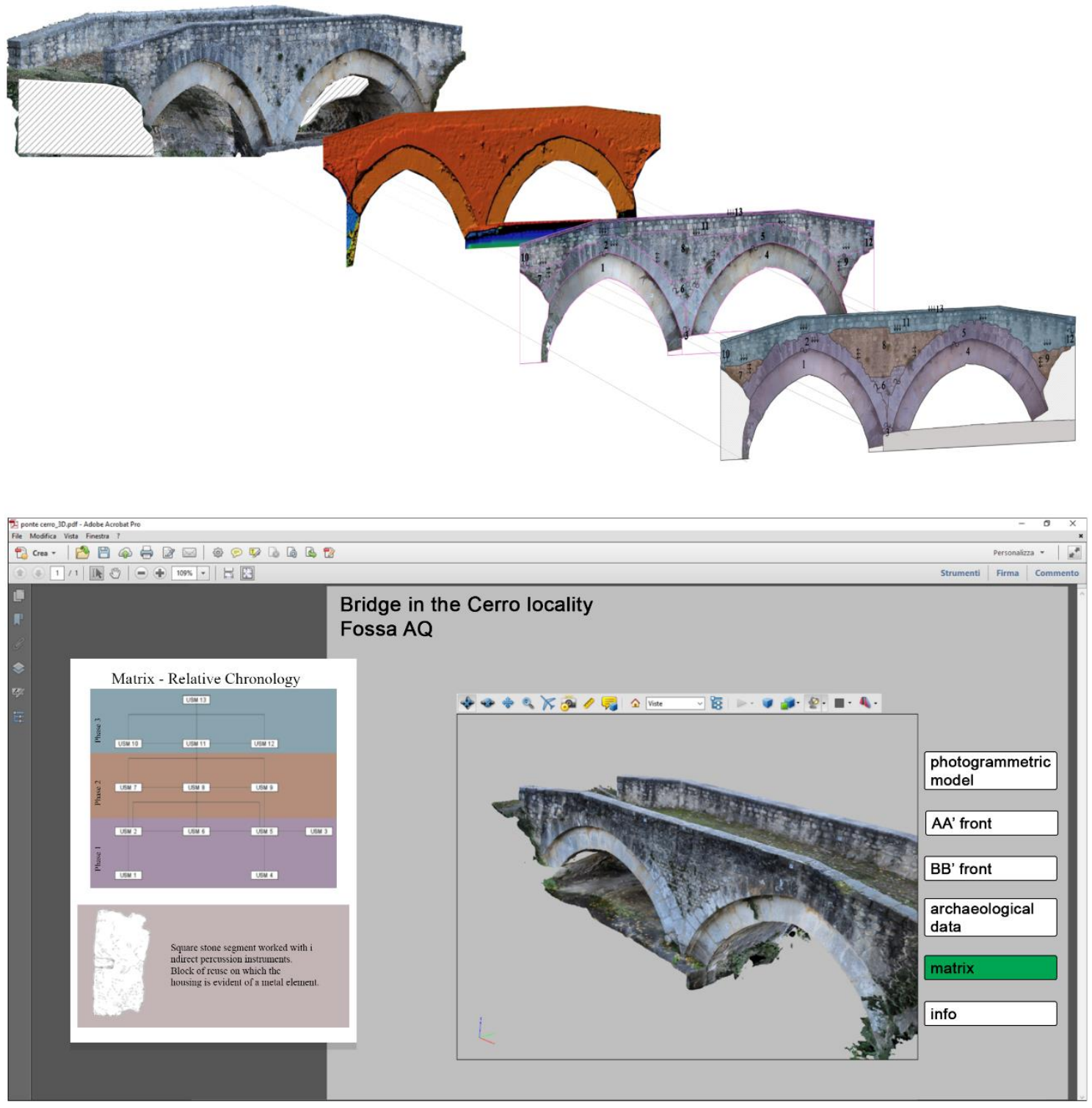

Figure 13. Photogrammetric bridge model mapped with the thematic results of the stratigraphic analysis. 


\section{Discussion and Final Remarks}

This paper reports some investigations and early results of a wider research on masonry arch bridges and is instrumental in the definition of an operational workflow able to combine the technical needs of knowledge for a reliable maintenance of operational bridges and those associated to the preservation of assets belonging to the architectural and landscape heritage due to their immaterial value. The paper summarized the operational workflow and results of the application and optimization of a well-known technique used by archaeologists to the inspection and maintenance of bridges. Compared to the census phases of historical structures and their typological and structural classification, the archaeological test on the masonries of bridges is at an initial phase. However, the experimentation validated the effectiveness of the archaeological approach for the analysis of historical bridges. The implementation of the stratigraphic method and the integration between different disciplines facilitates the identification of ancient undocumented action, overcoming the limit of the absence of written sources. It can be argued that the proposed procedure increases knowledge and facilitates the drafting of records on the state of health of historical bridges. The results, indeed, show how interdisciplinary approaches significantly increase and enhance the knowledge of infrastructural cultural heritage.

Moreover, the potentialities of integration between archaeological results and indirect survey carried out with photogrammetric technologies are assessed. These digital presentations of the metric and informative data collected, starting from the composition of SUMs for one bridge located in the Valley of the Aterno River, have been used as a visual inspection tool. The resulting digital model appears to fulfill the requirements of the monitoring and maintenance of road networks and offers interesting opportunities to structural engineers, who are in charge of the structural modeling and the related performance assessment under service and environmental loads, like those associated to earthquakes. This is of paramount importance for the structures still in use that have different problems, particularly from a structural point of view due to the changed loading conditions they are currently subjected to.

Despite the encouraging results, further work is needed to set an effective operational workflow that may track the acquired data and support the engineers in taking proper decisions in preserving safety and operation of the bridges based on reliable condition assessment information. The data resulting from the two different levels of knowledge described above will be put into production with the definition of digital procedures for data management. Moreover, the potentialities of the indirect survey carried out by integrating different digital tools and technologies (drone, terrestrial laser scanner and mobile scanning solutions as well as low-cost solutions like iPad Pro with LiDAR 3D Scanner) are assessed. It is worth noting that the described survey apparatus is in the line of the ordinary hardware available to technical personnel and inspectors in charge of the periodic inspections of bridges. This circumstance is far more relevant in the case of minor but valuable assets that are analyzed in the present paper, as more sophisticated and resource-consuming solutions are more compatible with more complex and critical infrastructures. This is not a trivial issue in the case of Inner Areas, where accessibility can be an issue, but natural resources and tourism can feed profitable crowd-based data collection [63].

This data will be preparatory to the implementation of a HBIM of masonry bridges in which the construction of the parametric model will consider the SUMs identified by the archaeological analysis and will allow integration, based on a scalar level of knowledge, with the GIS census system in its realization phase. The aim is to create a digital system for the management, archiving, visualization and sharing of Structural Health Monitoring data of historical masonry artifacts. The theme of monitoring for conserving and protecting these assets is evident and topical as they are part of the collective memory of the territory, which, among other things, is extremely fragile due to the high hydrogeological risk in the area. For this type of structure, one must also consider the danger of river flooding, which is increasingly caused today by particular weather conditions. Historical floods that 
may have caused collapse or structural failure must be considered in this context. Some of these events with consequent damage to bridges are documented in the chronicles [77]. In addition, it is also important to analyze the artifacts in relation to the course of the river, its original conformation, and any transformations of the riverbed, such as changes to the banks, diversions of the river course, and so on.

In conclusion, the modeling and representation tools for the creation of digital replicas (GIS, semantic three-dimensional models, and HBIM) will be integrated to validate complex digital models. Therefore, data from water level monitoring systems, located on more fragile and exposed structures, will become essential to complement HBIM and transform it into digital twin [78,79]. This will guarantee the multilevel use of built heritage data, interoperability, and accessibility, also due to Augmented Reality (AR) and Virtual Reality (VR) applications for visual inspection.

Author Contributions: Conceptualization, investigation, and methodology, F.S., C.R., G.F. and I.T.; validation and formal analysis, F.S. and I.T.; resources, data curation, writing-original draft preparation, F.S.; writing-review and editing, supervision, C.R., I.T. and G.F. All authors have read and agreed to the published version of the manuscript.

Funding: The present study has been carried out in the framework of the PON RICERCA E INNOVAZIONE 2020 E FSC "INSIST" code ARS01_00913, whose financial support is acknowledged. Authors are also grateful for the additional support provided by the PRIN 2017 "SURMOUNTInnovative Systems for the UpgRade of MasOnry structUres and Non sTructural elements" research project (NO. 20173SJJF8).

Institutional Review Board Statement: Not applicable.

Informed Consent Statement: Not applicable.

Data Availability Statement: Not applicable.

Conflicts of Interest: The authors declare no conflict of interest.

\section{References}

1. Strano, E.; Nicosia, V.; Latora, V.; Porta, S.; Barthelemy, M. Elementary Processes Governing the Evolution of Road Networks. Sci. Rep. 2012, 2, 296. [CrossRef]

2. Barthelemy, M. Time Evolution of Road Networks. In Traffic and Granular Flow '13; Chraibi, M., Boltes, M., Schadschneider, A., Seyfried, A., Eds.; Springer: Cham, Switzerland, 2015. [CrossRef]

3. Linee Guida per la Classificazione e Gestione del Rischio, la Valutazione della Sicurezza ed il Monitoraggio dei Ponti Esistenti. Approvate dall'Assemblea Generale del Consiglio Superiore dei Lavori Pubblici in data 17-04-2020. Available online: https:/ / www.mit.gov.it/comunicazione/news/mit-approvate-le-linee-guida-per-la-sicurezza-dei-ponti (accessed on 26 November 2020).

4. Bianchi, N.; Giorcelli, M. Reconstruction Aid, Public Infrastructure, and Economic Growth. SSRN Electron. J. 2018. [CrossRef]

5. Giannetti, I. Civil Engineering Heritage: Country Profile-Italy. Proc. Inst. Civ. Eng. Eng. Hist. Herit. 2018. [CrossRef]

6. Noguera, J.; Copus, A. Inner Peripheries: What Are They? What Policies Do They Need? Agriregionieuropa 2016, 45. Available online: https:/ / agriregionieuropa.univpm.it/it/content/article/31/45/inner-peripheries-what-are-they-what-policies-do-theyneed (accessed on 26 November 2020).

7. Copus, A.; Mantino, F.; Noguera, J. Inner Peripheries: An Oxymoron or a Real Challenge for Territorial Cohesion? Ital. J. Plan. Pract. 2017, 7, 24-49. Available online: http:/ / www.ijpp.it/index.php/it/article/view/77 (accessed on 26 November 2020).

8. ICOMOS. ICOMOS Dublin Charter-TICCIH Principles for the Conservation of Industrial Heritage Sites, Structures, Areas and Landscapes. 2011. Available online: https://www.icomos.org/en/resources/charters-and-texts (accessed on 15 November 2020).

9. Rafiee, A.; Vinches, M. Mechanical Behaviour of a Stone Masonry Bridge Assessed Using an Implicit Discrete Element Method. Eng. Struct. 2013, 48, 739-749. [CrossRef]

10. Domede, N.; Sellier, A.; Stablon, T. Structural Analysis of a Multi-Span Railway Masonry Bridge Combining in Situ Observations, Laboratory Tests and Damage Modelling. Eng. Struct. 2013, 56, 837-849. [CrossRef]

11. Ataei, S.; Alikamar, M.J.; Kazemiashtiani, V. Evaluation of Axle Load Increasing on a Monumental Masonry Arch Bridge Based on Field Load Testing. Constr. Build. Mater. 2016, 116, 413-421. [CrossRef]

12. Arêde, A.; Costa, C.; Topa Gomes, A.; Menezes, J.E.; Silva, R.; Morais, M.; Gonçalves, R. Experimental Characterization of the Mechanical Behaviour of Components and Materials of stone Masonry Railway Bridges. Constr. Build. Mater. 2017, 153, 663-681. [CrossRef] 
13. Elyamani, A.; Roca, P. A Review on the Study of Historical Structures Using Integrated Investigation Activities for Seismic Safety Assessment. Part II: Model Updating and Seismic Analysis. Sci. Cult. 2018, 4, 29-51. [CrossRef]

14. Pouraminian, M.; Pourbakhshian, S.; Noroozinejad Farsangi, E.; Berenji, S.; Keyani Borujeni, S.; Moosavi Asl, M.; Moahammad Hosseini, M. Reliability-Based Safety Evaluation of the Bistoon Historic Masonry Arch Bridge. Civ. Environ. Eng. Rep. 2020, 30, 87-110. [CrossRef]

15. Accornero, F.; Lacidogna, G. Safety Assessment of Masonry Arch Bridges Considering the Fracturing Benefit. Appl. Sci. 2020, 10, 3490. [CrossRef]

16. Addessi, D.; Liberatore, D.; Nocera, M. Damaging Behavior of Masonry Arch Bridges: Analysis of 'Ponte delle Torri' in Spoleto, Italy. J. Earthq. Eng. 2020, 1-26. [CrossRef]

17. Zampieri, P.; Perboni, S.; Tetougueni, C.D.; Pellegrino, C. Different Approaches to Assess the Seismic Capacity of Masonry Bridges by Non-linear Static Analysis. Front. Built Environ. 2020, 6, 47. [CrossRef]

18. Sotoudeh, S.; Jahangiri, M.; Ranjbarnia, M.; Zakeri, J.A. Three-dimensional Modeling of an Old Masonry Bridge and Assessing Its Current Capacity. Period. Polytech. Civ. Eng. 2020, 64, 460-473. [CrossRef]

19. Lubowiecka, I.; Arias, P.; Riveiro, B.; Solla, M. Multidisciplinary Approach to the Assessment of Historic Structures Based on the Case of a Masonry Bridge in Galicia (Spain). Comput. Struct. 2011, 89, 1615-1627. [CrossRef]

20. Solla, M.; Caamaño, C.; Riveiro, B.; Lorenzo, H. GPR Analysis of a Masonry Arch for Structural Assessment. In Proceedings of the 2011 6th International Workshop on Advanced Ground Penetrating Radar (IWAGPR), Aachen, Germany, 22-24 June 2011; pp. 1-6. [CrossRef]

21. Omer, M.; Margetts, L.; Mosleh, M.H.; Hewitt, S.; Parwaiz, M. Use of Gaming Technology to Bring Bridge Inspection to the Office. Struct. Infrastruct. Eng. 2019, 15, 1292-1307. [CrossRef]

22. Banfi, F.; Barazzetti, L.; Previtali, M.; Roncoroni, F. Historic Bim: A New Repository for Structural Health Monitoring. Int. Arch Photogramm. Remote Sens. Spat. Inf. Sci. 2017, 42, 269-274. [CrossRef]

23. Previtali, M.; Barazzetti, L.; Banfi, F.; Roncoroni, F. Informative Content Models for Infrastructure Load Testing Management: The Azzone Visconti Bridge in Lecco. Int. Arch. Photogramm. Remote Sens. Spat. Inf. Sci. 2019, XLII-2/W11, 995-1001. [CrossRef]

24. Pepe, M.; Costantino, D.; Restuccia Garofalo, A. An Efficient Pipeline to Obtain 3D Model for HBIM and Structural Analysis Purposes from 3D Point Clouds. Appl. Sci. 2020, 10, 1235. [CrossRef]

25. Conti, A.; Fiorini, L.; Massaro, R.; Santoni, C.; Tucci, G. HBIM for the Preservation of a Historic Infrastructure: The Carlo III bridge of the Carolino Aqueduct. Appl. Geomat. 2020. [CrossRef]

26. Rodriguez-Navarro, P.; Verdiani, G. Digital survey and interpretation of a fortification fragment: The Cadi bridge at the feet of the Alhambra hill, Granada, Spain. In Proceedings of the 2013 Digital Heritage International Congress (Digital Heritage), Marseille, France, 28 October-1 November 2013; pp. 363-366. [CrossRef]

27. Bertocci, S.; Bigognari, M.; Ricciarini, M. Digital survey for landscape knowledge: Garfagnana case studies for Tourism Development and Versilia Case Study for Hydraulic Analysis. DisegnareCon 2019, 12. Available online: http://disegnarecon. univaq.it/ojs/index.php/disegnarecon/article/view/575 (accessed on 26 November 2020).

28. Germanò, G. The Roman Bridge of Canosa di Puglia: A Metrological Approach. In Proceedings of the 2020 IMEKO TC-4 International Conference on Metrology for Archaeology and Cultural Heritage, Trento, Italy, 22-24 October 2020; pp. 598-603.

29. Inglese, C.; Paris, L. (Eds.) Arte e Tecnica dei Ponti Romani in Pietra; Sapienza Università Editrice: Roma, Italy, 2020.

30. Cagnana, A. Archeologia delle Strade: Finalità di Ricerca e Metodi di Indagine. Archeologia dell'Architettura 1996, I, 71-74.

31. Quiros Castillo, J.A. (Ed.) Archeologia delle Strade nel Medioevo. In L'Ospedale di Tea e l'Archeologia delle Strade della Valle del Serchio; All'Insegna del Giglio: Firenze, Italy, 2000.

32. De Minicis, E. Archeologia delle Strade: La Viabilità in Età Medievale; Metodologie ed Esempi di Studio a Confronto, Atti del I Convegno Nazionale di Studi (Viterbo-Roma, 3-4 Dicembre 2009); Aracne: Roma, Italy, 2015.

33. Romano, M.G. La Via Latina nel Territorio delle Valli del Titerno e Telesona: Analisi dei Ponti. In Archeologia delle Strade: La Viabilità in età Medievale; Metodologie ed Esempi di Studio a Confronto, Atti del I Convegno Nazionale di Studi (Viterbo-Roma, 3-4 Dicembre 2009); De Minicis, E., Ed.; Aracne: Roma, Italy, 2015; pp. 63-70.

34. Alvaro, C. Il Ponte di Statua sulla Via Aurelia. In Archeologia delle Strade: La Viabilità in Età Medievale; Metodologie ed Esempi di Studio a Confronto, Atti del I Convegno Nazionale di Studi (Viterbo-Roma, 3-4 Dicembre 2009); De Minicis, E., Ed.; Aracne: Roma, Italy, 2015; pp. 55-62.

35. Fiorini, A. An Urban Archeological Project in Rimini. Preliminary Report (2017-2018). The Contribution of Building Archaeology to Research and Conservation. Groma 2018, 3. [CrossRef]

36. Vegas, F.; Mileto, C. La Restauración del Puente Medieval Sobre el Río de las Truchas. Loggia. Arquit. Restauración 2008, 21, 106-123. [CrossRef]

37. Continenza, R.; Trizio, I. I Mulini della Valle dell'Aterno: Rilevamento e Restauro. In $9^{\circ}$ Congreso Internacional De Molinologia. Actas. Murcia; Fernandez Ruiz, P.J., Ed.; Diego Marin Librero Editor: Murcia, Spain, 2017; pp. 64-74.

38. Azkarate, A. La Arqueología de la Arquitectura a Revisión. Arqueología de la Arquitectura 2020, 17, e101. [CrossRef]

39. Mannoni, T. Metodi di datazione dell'edilizia storica. Archeol. Archit. 1984, XI, 396-403.

40. Brogiolo, G.P. Archeologia dell'Edilizia Storica; New Press: Como, Italy, 1988.

41. Parenti, R. Archeologia dell'Architettura. In Dizionario di Archeologia; Francovich, R., Manacorda, D., Eds.; Laterza: Roma, Italy, 2000. 
42. Parenti, R. Dalla Stratigrafia all'Archeologia dell'Architettura. Alcune Recenti Esperienze del Laboratorio Senese. Arqueol. Arquit. 2002, 1, 74-82. [CrossRef]

43. Brogiolo, G.P. Introduzione. Atti del convegno Archeologia dell'Architettura: Temi e Prospettive di Ricerca. (Sala Conferenze del Forte di Gavi (AL). Archeol. Archit. 2010, XV,11-14.

44. Francovich, R. Archeologia e Informatica: Dieci Anni Dopo. Archeol. Calc. 1999, 10, 45-61.

45. D'Andrea, A.; Niccolucci, F. L'archeologia Computazionale in Italia: Orientamenti, Metodi e Prospettive. Archeol. Calc. 2000, 11, 13-31.

46. D'Andrea, A. Documentazione Archeologica, Standard e Trattamento Informatico; Archaeolingua: Budapest, Hungary, 2006.

47. Fronza, V.; Nardini, A.; Valenti, M. (Eds.) Informatica e Archeologia Medievale. L'Esperienza Senese; All'insegna del Giglio: Firenze, Italy, 2009.

48. Cattani, M.; Fiorini, A.; Viggiani, N. (Eds.) Nuove Frontiere dell'Archeologia: Il Trattamento del Dato Tridimensionale. Atti del Seminario (Ravenna 2004); CD-ROM; Università degli Studi di Bologna: Bologna, Italy, 2004; pp. 1-12.

49. Campana, S.; Francovich, R. (Eds.) Laser Scanner e GPS. Paesaggi Archeologici e Tecnologie Digitali; All'insegna del Giglio: Firenze, Italy, 2006 .

50. Drap, P.; Durand, A.; Nedir, M.; Seinturier, J.; Papini, O. Photogrammetry and Archaeological Knowledge: Toward a 3D Information System Dedicated to Medieval Archaeology: A Case Study of Shawbak Castle in Jordan. 3D ARCH. 2007. Available online: https:/ / halshs.archives-ouvertes.fr/halshs-00277373/document (accessed on 5 January 2021).

51. Peripimeno, M. Rilievo di Monumenti e Stratigrafie: l'Uso del Laser Scanner. In Informatica e Archeologia Medievale. L'Esperienza Senese; Fronza, V., Nardini, A., Valenti, M., Eds.; All'Insegna del Giglio: Firenze, Italy, 2009; pp. 111-129.

52. Fiorini, A. Rilievo Archeologico Mediante Dispositivo Scanner Laser 3D. Verso una Registrazione Tridimensionale Delle Evidenze Stratigrafiche: 1'Edificio 2-Magazzino-nel Sito Archeologico di Classe. In Principi di Laser Scanning 3D. Hardware, Metodologie Applicative, Esempi; Bartolucci, D., Ed.; Flaccovio: Palermo, Italy, 2009; pp. 100-105.

53. Fiorini, A.; Archetti, V. Fotomodellazione e stereofotogrammetria per la creazione di modelli stratigrafici in archeologia dell'architettura. Archeol. Calc. 2011, 22, 199-216.

54. Fiorini, A. Tablet PC, Fotogrammetria e PDF 3D: Strumenti per Documentare 1'Archeologia. Archeol. Calc. 2012, $23,213-227$.

55. Brogiolo, G.P. Campionatura e Obiettivi nell'Analisi Stratigrafica degli Elevati. In Archeologia e Restauro dei Monumenti. I ${ }^{\circ}$ Ciclo di Lezioni sulla Ricerca Applicata in Archeologia, (Pontignano 1987); Francovich, R., Parenti, R., Eds.; All'insegna del Giglio: Firenze, Italy, 1988; pp. 335-346.

56. Doglioni, F. Stratigrafia e Restauro. Tra Conoscenza e Conservazione dell'Architettura; Lint Editoriale: Trieste, Italy, 1997.

57. Beltramo, S. Stratigrafia dell'Architettura e Ricerca Storica; Carrocci: Roma, Italy, 2009.

58. Conforti, C.; Hopkins, A. (Eds.) Architettura e Tecnologia. Acque, Tecniche e Cantieri nell'Architettura Rinascimentale e Barocca; Nuova Argos: Roma, Italy, 2002.

59. Brogiolo, G.P.; Cagnana, A. Archeologia dell'Architettura. Metodi e Interpretazioni; All'insegna del Giglio: Firenze, Italy, 2012.

60. Francovich, R.; Parenti, R. (Eds.) Archeologia e Restauro dei Monumenti; All'Insegna del Giglio: Firenze, Italy, 1988.

61. Brogiolo, G.P. Dall'Archeologia dell'Architettura all'Archeologia della Complessità. Pyrenae 2007, 38, 7-38.

62. Manuale per la Valutazione dello Stato dei Ponti; CIAS: Bolzano, Italy, 2004.

63. Marra, A.; Fabbrocino, G. Crowd-based Tools for Indirect Condition Assessment and Conservation of Cultural Heritage. In Digital Heritage, Progress in Cultural Heritage: Documentation, Preservation and Protection, Proceedings of the 8th International Conference, EuroMed 2020; in press.

64. Fiorini, A. Modelli Interattivi 3D nei File PDF. Applicazioni in Campo Archeologico. In Archeologia Virtuale. Comunicare in Digitale, Atti del III Seminario (Roma, 19-20 giugno 2012); Gianolio, S., Ed.; Espera: Roma, Italy, 2013; pp. 72-84.

65. Murphy, M.; McGovern, E.; Pavia, S. Historic building information modelling (HBIM). Struct. Surv. 2009, 27, 311-327. [CrossRef]

66. Geoportale Regione Abruzzo. Available online: http://geoportale.regione.abruzzo.it/Cartanet (accessed on 10 October 2020).

67. Di Vincenzo, B. Augfinum. In Emergenze Storico-Architettoniche nel Comune di Fagnano Alto (AQ); Palumbo: Teramo, Italy, 2018.

68. Archivio di Stato dell'Aquila, Prefettura, Serie I ${ }^{\circ}$, Affari generali, Categoria 20; Ponti e Strade Nazionali.

69. Moro, L.; Neri, A. (Eds.) Linee guida per la valutazione e riduzione del rischio sismico del patrimonio culturale: Allineamento alle nuove Norme tecniche per le costruzioni: Circolare n. 26, 2 dicembre 2010/Ministero per i beni e le attività culturali, Segretariato generale; Gangemi: Roma, Italy, 2010.

70. NTC. Ministerial Decree 17 January 2018. Updating of Technical Standards for Construction; G.U. n. 42 20/02/2018; NTC: Roma, Italy, 2018. (In Italian)

71. ICOMOS. ICOMOS Charter-Principles for the Analysis, Conservation and Structural Restoration of Architectural Heritage. 2003. Available online: https:/ / www.icomos.org/en/charters-and-other-doctrinal-texts (accessed on 26 November 2020).

72. Hutchinson, M.; Gallant, J.C. Digital Elevation Models and Representation of Terrain Shape. In Terrain Analysis: Principles and Applications; Wilson, J.P., Gallant, J.C., Eds.; Wiley: New York, NY, USA, 2000; pp. 29-50.

73. Zoni, F. L'uso della Tecnologia DEM nella Documentazione Archeologica. Archeol. Calc. 2017, 28, $219-238$.

74. Bertocci, S.; Minutoli, G.; Pancani, G. Rilievo Tridimensionale e Analisi dei Dissesti della Pieve di Romena. Disegnarecon $2015,8,14$.

75. Arrighetti, A. Registering and Documenting the Stratification of Disruptions and Restorations in Historical Edifices. The contribution of Archaeoseismology in Architecture. J. Archaeol. Sci. Rep. 2019, 23, 243-251. [CrossRef] 
76. Pancani, G.; Bigongiari, M. Digital Survey for the Structural Analysis of the Verruca Fortress. Procedia Struct. Integr. 2020, 29, 149-156. [CrossRef]

77. Di Buccio, A. Delle Cose dell'Aquila (1362-1382). In Antiquitates Italicae Medii Evii, vol. VI; Muratori, L.A., Ed.; ex Typographia Societatis Palatinae in Regia Curia: Roma, Italy, 1742; col. 796, st. 707.

78. Jouan, P.; Hallot, P. Digital Twin: A HBIM-Based Methodology to Support Preventive Conservation of Historic Assets through Heritage Significance Awareness. Int. Arch. of the Photogramm. Remote Sens. Spat. Inf. Sci. 2019, XLII-2/W15, 609-615. [CrossRef]

79. Jouan, P.; Hallot, P. Digital Twin: Research Framework to Support Preventive Conservation Policies. Int. J. Geo-Inf. 2020, 9, 228. [CrossRef] 